\title{
T.F. Torrance: Union with Christ through the Communion of the Spirit
}

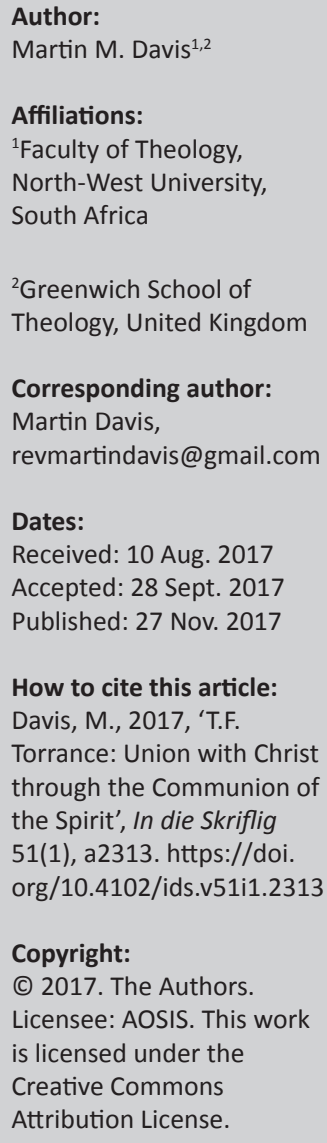

Union with Christ is a heuristic, over-arching rubric for the discussion of many themes in Torrance's soteriology. Union with Christ, however, has not been a major topic in Torrance studies. The purpose of this article is to address this inadequacy.

The present article provides an overview of Torrance's discussion of incarnational reconciliation and 'vicarious humanity' of Jesus Christ. According to Torrance, the hypostatic union is a dynamic, atoning union in which humanity is cleansed of sin and brought into sanctifying union with God. Throughout his earthly life, Jesus acts 'vicariously', reconciling humanity to God and sanctifying every stage of human life, so that union with Christ is fully and objectively accomplished for all humanity in Jesus.

All aspects of Christian life, including faith, justification and sanctification are fully realised for all in the incarnate life of Christ. The objective union, established in the incarnation, is subjectively realised in the life of the believer through the communion of the Holy Spirit. In response to the objective reality of grace, believers are summoned to take up the cross and follow Jesus.

Torrance's assertion of union with Christ as a fait accompli in the incarnation and vicarious act of Christ raises questions regarding the subjective human response to salvation as well as the issue of universalism.

Content is based on a review of primary literature published by Torrance over a span of more than 40 years as well as a review of recent secondary resources that include some aspect of the subject.

\section{Introduction}

Thomas F. Torrance (1913-2007) is widely regarded as the most important British academic theologian of the 20th century. Many regard Torrance as the most outstanding Reformed theologian in the Anglo-Saxon world (Colyer 2001:15; McGrath 1999:xi; Molnar 2009:1). A steadily growing volume of secondary literature attests to Torrance's importance for contemporary theology. In recent years, a number of published books have highlighted various aspects of Torrance's theology. ${ }^{1}$

\section{Union with Christ}

Union with Christ is a heuristic, over-arching rubric for the discussion of many themes in Torrance's soteriology, including incarnational reconciliation, the wonderful exchange, vicarious humanity, onto-relationality, faith, justification and sanctification. With the notable exception of Kye Won Lee's work (2003), however, 'union with Christ' has not been a major topic in Torrance studies, for this important topic is usually discussed as an aspect of other topics of soteriology. For example, Purves (2015:124) embeds union with Christ 'as one work within the magnificent exchange', while Habets (2009:93) asserts that union with Christ is 'underpinned' and 'informed by the more determinative doctrine of theosis'. Relegation of this important doctrine to the level of sub-heading is unwarranted, however, for, as Billings (2011:1) notes, 'union with Christ' is 'theological shorthand' for the gospel itself. Torrance (1992:66) attests to the importance of this doctrine by asserting that 'union with God in and through Christ' is the 'goal and end' of God's reconciling act in Jesus Christ. In 'union with Christ', notes Torrance, we are reconciled to the Father, justified, sanctified and taken up by the Spirit into the communion of the holy Trinity. ${ }^{2}$

1.Spiedell (2016) on the relationship between Torrance's soteriology and Christian ethics; Radcliff (2016) on salvation and sanctification in the Torrance tradition; Eugenio (2015) on Torrance's 'Trinitarian soteriology'; Habets (2013) on Torrance's theology and method Stamps (2013) on Torrance's view of the Eucharist; Chung (2011) on the mediation of revelation and reconciliation in Torrance's theology; MacLean (2012) on Torrance's eschatology; and Habets (2009:ix, 1) on theosis as a 'controlling metaphor' for Torrance's theology; MacLean (2012) on Torrance's eschatology; and Habets (2009:ix, 1) on theosis as a 'contr.
soteriology. For an older work on the practical aspects of living in union with Christ, see Lee (2003).

2.While this article focuses on 'union with Christ' in Torrance's theology, it is important to remember that, for Torrance (1992:66), the telos of union with Christ is Trinitarian, that is, the goal for humanity is 'to participate in the very light, life and love of the Holy Trinity'. 
We begin our examination of Torrance's doctrine of union with Christ with an overview of his discussion of incarnational reconciliation and vicarious humanity. According to Torrance, union with Christ is fully and objectively accomplished for all humanity in the incarnation of Jesus Christ and his 'vicarious humanity' as lived out through the course of his earthly life. Torrance's objective soteriology does not go unchallenged, however. Critics argue that Torrance pays insufficient attention to the role of the Holy Spirit as well as the subjective (i.e. personal) response of faith in his soteriology. Torrance's assertion of universal election also attracts charges of universalism. These criticisms are addressed in the 'Critique' below.

\section{Incarnational reconciliation}

According to Torrance (1992:64-66; cf. Cassidy 2008:165, 166), the hypostatic union of God and humanity in Jesus is union with Christ, that is, union with Christ is objectively accomplished for all humanity in the incarnation itself. Torrance (1992:65) does not regard the union of divine and human natures in the one person of Jesus Christ as a merely 'static' union; rather, the hypostatic union is a 'reconciling union' or a 'dynamic atoning union' wherein the actual condition of human estrangement is brought into 'perfect sanctifying union' with God through the incarnation and earthly life of Jesus. According to Eugenio (2015:72), Torrance's assertion of salvation, as taking place 'in Christ', flows logically from his understanding of Christ's incarnational redemption'. ${ }^{3}$ According to Torrance, 'Union with Christ ... must primarily be understood as the reconciling initiative of God accomplished ontologically through Christ's incarnate life'. As Eugenio (2015:72 notes, '[B]ecause of the hypostatic union, there exists now an unbreakable ontological bond between God and humanity' - a bond accomplished within the person of Jesus Christ.

The doctrine of the hypostatic union constitutes the 'objective heart' of Torrance's doctrine of atoning reconciliation (Torrance 2008:195). In the union of divine and human nature in Jesus Christ, God reconciles humanity to himself in a single, unitary movement of grace that is at once humanward and Godward (Torrance 1992:73). As Torrance (1996:153) notes, 'through his incarnational union with us, he has established our union with him ... Through his incarnational fraternity, that which was lost in Adam is restored.'

In Torrance's thought (1988:159; cf. 1992:66), the incarnation and the atonement are inextricably linked: incarnation is inherently redemptive and redemption is inherently incarnational. ${ }^{4}$ According to Torrance (2002:151), reconciliation or atonement is not an 'act' done by Christ; rather, it is the person of Christ himself 'in activity'. The redemptive activity of Christ finds its significance in the 'person' who does it. Therefore, atoning reconciliation must be understood as

3.Eugenio's reference to 'logic' is misplaced, however, because Torrance (1993:246, 247) adamantly resists 'logico-causal' explanations of incarnational reconciliation.

4.Following Barth (1936-1977, IV.1.2.3), Torrance fully integrates Christology and soteriology into a unitary whole. accomplished within the incarnate constitution of Jesus Christ. Torrance (1986) writes:

Jesus Christ does not mediate a reconciliation (any more than a revelation) other than what he is in himself, as though he were merely the intermediary or instrument of divine reconciliation. He embodies in himself what he mediates, for what he mediates and what he is are one and the same. He himself in the wholeness of his Person, Word and Act is the content and reality of divine Reconciliation. He is the Propitiation for our sins; he is our Redemption; he is our Justification. It is in this identity between Mediator and Mediation that the living heart of the Gospel is to be found. (pp. 475, 476)

Torrance (1996:158) regards 'union with Christ' as part of a 'miraculous commerce' between God and humanity wherein we share in the benefits of Christ's atoning exchange (cf. Dawson 2007:62; Eugenio 2015:73). According to Torrance (1988), the 'wonderful exchange' embedded in the incarnation is:

the redemptive translation of man from one state into another brought about by Christ who in his self-abnegating love took our place that we might have his place, becoming what we are that we might become what he is. (p. 179)

In the 'wonderful exchange', Christ assumes our poverty while giving us his riches (cf. Calvin 2008, IV.17.2). The miraculous commerce of the wonderful exchange is worked out internally, that is, within the incarnation itself, in the ontological depths of the sinful Adamic flesh the incarnate Son assumed. ${ }^{5}$ The wonderful exchange reaches its appointed end through Christ's 'transforming consecration of us in himself and through his exaltation of us as one body with himself into the immediate presence of the Father' (Torrance 1988:181) As Deddo (2007:138-141) notes, our union with God through the wonderful exchange, wherein our redeemed, recreated humanity is lifted to heaven in the risen Saviour, harmonises with Paul's assertions that not only have we 'codied' with Christ, but we have been 'co-raised' with him, so that we are truly seated with God in heavenly places.

According to Torrance, the dynamic, reconciling union of God and humanity in Jesus Christ effects an ontological transformation that reverberates throughout the cosmos, reconciling all things to God in Christ and setting humanity on a new footing with God. In Jesus Christ, argues Torrance, all humanity is chosen for salvation. Torrance (1949:315) writes:

The great fact of the Gospel then is this: that God has actually chosen us in Jesus Christ in spite of our sin, and that in the death of Christ that election has become a fait accompli. It means too that God has chosen all men, in as much as Christ died for all men, and because that is once and for all no one can ever elude the election of His love. In as much as no one exists except by the Word of God by whom all things were made and in whom all things consist, and in as much as this is the Word that has once and for all enacted the eternal election of grace to embrace all

5.Following the Patristic assertion that "the unassumed is the unhealed", Torrance (1988:161) argues that the eternal Word assumed fallen human flesh in the incarnation. The assumption of fallen flesh is a matter of current debate (see Davis
incen incarnatio). 
men, the existence of every man whether he will or not is bound up inextricably with that election - with the Cross of Jesus Christ. (pp. 248-253)

Torrance claims that election is a fait accompli wherein 'every man' is 'bound up inextricably' with the cross of Christ. Because Jesus Christ is the eternal Word of God by whom all things are created and in whom all things exist, there is an ontological relationship between the incarnate Word and all humanity. Torrance faults traditional Western views of atonement, whether satisfaction, penal substitution or moral example, for their failure to account for the ontological transformation of humanity that is effected in the union of divine and human natures in the incarnate constitution of Jesus Christ (Radcliff 2016:49). ${ }^{6}$ According to Torrance, atonement is ontological and internal to the person of Christ, that is, the hypostatic union of divine and human natures in Jesus is itself an atoning, reconciling, sanctifying union between God and sinful humanity. Union with Christ is effected in and through the incarnation itself and is objectively realised for the whole of humanity. For Torrance, Jesus is reconciliation between God and sinful humanity.

\section{Vicarious humanity}

In contrast to traditional theories of atonement that focus on the atoning significance of Christ's vicarious death, one of the strong points of Torrance's theology is his focus on the atoning significance of Jesus' entire life (Gill 2007:45, 46; Radcliff 2016:58). Following the Nicene fathers, Torrance (1988) argues that Jesus' life and not only his death on the cross was a priestly self-offering on our behalf:

$[A]$ s one of us and one with us, he shared all our experiences, overcoming our disobedience through his obedience and sanctifying every stage of human life, and thereby vivified and restored our humanity to communion with God. He sanctified himself for our sakes that we might be sanctified in him. (pp. 167, 168)

Torrance follows Calvin (2008, II.16.5; 327) in asserting that, as soon as Christ put on the form of a servant (cf. Phlp 2:7), he began to pay the price of liberation for our salvation. Throughout the whole course of his earthly life, 'as one of us', Jesus offered perfect faith and obedience to the Father, 'sanctifying every stage of human life'. The incarnate Son's humanward-Godward response of perfect faith and obedience constitutes the 'vicarious act' of Jesus Christ, speaking and acting 'as man', in place of and on behalf of all humanity. According to Torrance (1992):

We are to think of the whole life and activity of Jesus from cradle to the grave as constituting the vicarious human response to himself which God has freely and unconditionally provided for us. (p. 80)

6.According to Torrance (1986:461ff.) Western theories of atonement portray Christ's moral example. In these views, Jesus' sacrificial death appears to be conceived as an 'external transaction', wherein Jesus offers his body as an instrument of punishmen in order to satisfy the Father demands for justice. Torrance subsumes Western-Latin theories of the atonement under the rubric, 'The Latin Heresy'. In her typically irenic tone, Radcliff (2016:49) correctly notes that " $t$ ] he term "heresy" is strong language for Western Christians who are sincere and well-meaning in their faith ...'.
As our Representative and Substitute, notes Torrance, 'Jesus Christ is our human response to God.'

\section{The communion of the Spirit}

Having briefly examined Torrance's assertion that union with Christ is fully accomplished for all humanity in the hypostatic union and earthly life of Jesus, we turn now to the role of the Holy Spirit in Torrance's understanding of union with Christ.

In his book, The school of faith: The catechisms of the Reformed church, Torrance (1959) argues that the Reformed doctrine of 'communion of the Spirit' can otherwise be put as 'union with Christ through the Communion of the Spirit'. The communion of the Spirit is a correlate of the union of God and humanity wrought out in the incarnate life of Jesus Christ. That is, the Spirit actualises subjectively in the life of believers what has already been accomplished for them objectively in the incarnation of Jesus Christ. As Torrance notes:

Because the Communion of the Spirit is correlative to the incarnational union in Christ, we have to think of it as two-fold in relation to the human life and the work of Christ. (p. cvi)

In keeping with his disdain for dualism (Cassidy 2008:165), Torrance describes a 'unity-in-distinction', where 'union with Christ' and 'communion of the Spirit' are not two, separate realities, but rather distinct aspects of a single reality.

\section{One union in two relations}

Torrance (1959:cvi, cvii) engages 16th-century theologian John Craig to explicate the correlation between union with Christ and the communion of the Spirit. In his Catechism of 1581, Craig asserts both a carnal union and a spiritual union with Christ. 'Carnal union' refers to 'Christ's union with us and our union with Christ which He wrought out in his birth of the Spirit and in His human life through which $\mathrm{He}$ sanctifies us'. ${ }^{7}$ Because Christ was 'made man like us', notes Craig, 'life and righteousness are placed in our flesh'. Craig argues that 'those who are joined with Him spiritually' are sure of this life.

Craig's assertion of what appears to be two unions, 'carnal' and 'spiritual', raises an important question for Torrance (1959):

Is the spiritual union another union, a union in addition to our carnal union with Christ, or is it a sharing in the one and only union between God and man wrought out in Jesus Christ? That is a very important question, for if the spiritual union is an additional union, then our salvation depends not only on the finished work of Christ but upon something else as well which has later to be added on to it before it is real for us. (p. cvii)

Torrance (1959:cvii) argues that in both Roman Catholicism and Protestantism 'something else', in fact, is added to the union with Christ accomplished in the incarnation. In

7.Craig's carnal union appears to be equivalent to the hypostatic union of the eternal Word and humanity (i.e. the incarnation) as worked out in the earthly life of Jesus
Christ. 
Catholicism, union with Christ is effected through 'baptismal regeneration and ex opere operato sacramental incorporation into Christ'. In Protestantism, 'union with Christ ... is effected by faith or by conversion through which alone what Christ has done for us becomes real for us'. As Torrance notes, 'Both these forms of the same error lead to a doctrine of man's cooperation in his own salvation; and so involve a doctrine of conditional grace'. Therefore, argues Torrance (1959):

[I]t must be insisted that there is only one union with Christ, that which He has wrought out with us in His birth and life and death and resurrection and in which He gives us to share through the gift of His Spirit. (p. cvii)

According to Torrance, there is only one union with Christ, 'wrought out' with us in the incarnation and earthly life of Christ. We share in the one union by the gift of the Spirit. Torrance (1959) argues that 'carnal union', as described by Craig, includes Christ's:

whole life and work of saving obedience, so that when we speak of a spiritual union with Christ, that means that through the Spirit we are given to share in the covenanted obedience of Christ ... (p. cviii)

In this view, the Spirit's work is not additional to the work of Christ, but rather is the means by which we participate or share in the vicarious humanity of Jesus Christ.

Radcliff (2016:93) astutely observes that the one objective union with Christ achieved in the incarnation is expressed in two 'relations': First, an ontological 'relation' to Christ; and second, a pneumatological 'relation' to Christ. The ontological union, accomplished for all humanity in the incarnation and 'vicarious act' of Jesus, is a fait accompli. ${ }^{8}$ According to Torrance (1996:238; cf. Radcliff 2016:93), it is the role of the Spirit to open us up within our subjectivities for Christ, so that 'we find our life not in ourselves but out of ourselves, objectively in him'. Thus, it is important to be clear that, while the objective union with Christ is essential for humanity to be ontologically transformed and thus healed of its sin and corruption, union with Christ does not depend upon subjective human appropriation, for 'this would throw us back upon ourselves to achieve salvation, an impossible task' (Radcliff 2016:92).

\section{Onto-relations in union with Christ}

Torrance's assertion of one union in Christ in two 'relations' is supported by his articulation of the 'onto-relational' nature of reality. According to Torrance (1980:173-178; 1992:47), 'onto-relations' are 'being-constituting' relations. Contra the atomistic-individualism of Western thought, entities exist not as isolated particles, but in webs of relationships where the relations themselves constitute the 'being' of the realities in question. In human terms, our identities as 'persons' are determined not only by our existence as distinct individuals, but also by the relationships in which we live and move. Thus, 'onto-relations' make us 'who we are'.

8.'However', as Radcliff (2016:93) rightly notes, 'we can live in ignorance or denial o this or we can live in agreement with it and enjoy its reality'.
According to Torrance (1981:28; 1992:46-50), 'being' itself, whether divine or human, is 'onto-relational', that is, relationship is essential to identities. Thus, if relationship is 'constitutive' rather than merely 'accidental' (as Aristotle claimed), argues Deddo (2007:142, 143), 'then the Triune God who has his being as Father, Son and Holy Spirit reconstitutes our humanity by forging a new relationship with fallen humanity' through the incarnation and earthly life of Christ, 'the New Adam'. 9 In short, given that our identities are formed in relationships, in union with Christ our fallen Adamic 'being' is reconstituted so that we really are 'new creations' in Christ (2 Cor 5:17).

In union with Christ, notes Deddo (2007:144), we are most truly ourselves, for this union 'is a continual relationship with Christ at the deepest levels of our being, not a confusion of ourselves with Christ'. In union with Christ, as Purves (2015:125) argues, we do not 'become Jesus', that is, personal identity is not lost. Rather, distinction of persons is maintained, while a personal 'exchange' takes place (2 Cor 8:9). In union with Christ, we remain 'who we are', but our humanity is established and fulfilled in Christ without confusion. ${ }^{10}$ As Deddo (2007:145) notes, salvation is a 'relational reality'. Union with Christ is a 'dynamic relationship' of mutual giving and receiving that 'determines the essence of who we are and who we are becoming'.

Since the 'essence of who we are' is constituted in relationship, we must assert the importance of both the ontological and relational aspects of union with Christ in order to insure a proper view of salvation (Dearborn 1989:290). An ontorelational view of salvation ascribes significance both to the objective ontological transformation of our humanity in Jesus as well as the subjective participation in that transformation by the Spirit. Thus, salvation is not automatic and impersonal as though it were accomplished solely in the incarnation in the absence of the distinct personalising work of the Spirit (cf. Deddo 2007:144). Nor is salvation solely relational as if it were merely an extrinsic encounter through 'personal faith' without an ontological transformation of our humanity. Rather, salvation is 'onto-relational', because it involves an ontological transformation of our humanity in the incarnation and 'vicarious act' of Christ that is realised in each of us personally through our relationship with Christ in the Spirit.

\section{Faith, justification and sanctification}

We may better understand Torrance's assertion of the objective reality of union with Christ by briefly examining his understanding of saving faith, justification and sanctification in relation to the 'vicarious humanity' of Jesus Christ. Following Barth (1936-1977, IV.2:517), Torrance contends

9.As Deddo (2007:143) notes, "Jesus Christ has become our Lord from the inside of our humanity.'

10.According to Torrance (1988:179-181; 1992:65; 1996:243), 'union with Christ', as fully accomplished for all humanity in the incarnate life of Christ, involves not only the healing and renewing of our fallen humanity, but also the restoration of relationships and consequent new life in union with God. Torrance (1996:153) writes, ' $[T]$ hrough his incarnational union with us, he has established our union writes, $[T]$ hrough his incarnational union with us, he has established our union
with him ... Through his incarnational fraternity, that which was lost in Adam is restored.' 
that justification and sanctification are objectively and fully realised for all in union with Christ. According to Torrance (1959:cx; cf. 1996:158), we participate in the 'benefits' of Christ through the incarnation: '[I]t was through his becoming one with us first in his Incarnation that Christ wrought our justification for us.' Justification is an objective reality appropriated for us by Jesus Christ who rendered to the Father the perfect faith and obedience we are unable to offer. In the union with Christ, humanity is made to share in Jesus' justification before God (Torrance 1960:228, 233).

Torrance turns to Galatians 2:20 to support his doctrine of the 'vicarious act' of Christ for our salvation. Torrance (1994) translates this passage as follows:

I am crucified with Christ, nevertheless I live, yet not I. But Christ lives in me, and the life which I now live in the flesh, I live by the faith of the Son of God, who loved me and gave himself for me. (p. 31, [author's emphasis] $)^{11}$

As Purves (2015:130) rightly notes, according to Torrance, 'the whole of the Christian life in all regards is included in the "I yet not I but Christ".

In regard to the relationship between Jesus' vicarious faith and the subjective response of faith, Torrance (1959) writes:

In His obedient human life, Jesus Christ was not only the Son of God drawing near to us in the flesh, but in and out of our flesh He lived a life of perfect obedience and trust and confidence toward God the Father, a perfectly faithful life, in which His obedience and faith toward God were part of His vicarious and atoning life, part of His sanctified human nature. It is in that very human nature, with its faith and obedience, that we are given to participate through the Communion of the Spirit, and that is the very foundation of our faith in Him and the ground of our obedience to the Father. (pp. cviii, cix)

In view of Christ's vicarious faith, argues Torrance (1959:cix), we are not saved 'by the act of our believing'. Rather, it is Christ's own act of believing that saves us. In regard to the 'locus' of justifying faith, Torrance (1960) writes:

Through union with [Christ] we share in his faith, in his obedience, in his trust and appropriation of the Father's blessing; we share in his justification before God. Therefore when we are justified by faith, this does not mean that it is our faith that justifies us, far from it - it is the faith of Christ alone that justifies us ... That is what it means to be justified by faith. (p. 236)

According to Torrance, justification by 'faith' does not refer to the believer's personal response of faith. Rather, it refers to the believer's subjective inclusion in Christ's vicarious faith. We are not justified by a 'personal decision' of faith 'in' Jesus, but by the faithfulness 'of' Jesus. Torrance (1960:233) argues that Jesus is 'the great Believer', who vicariously believes for us. In the hypostatic union, Jesus 'embodies' the divine act of justification from the side of God and the 'appropriation' of justification from the side of humanity, so that both the objective (i.e. God-humanward) and subjective (i.e. human-
Godward) aspects of justification are fulfilled in his incarnate person. Therefore, Torrance argues (1959:cix), we cannot talk seriously about 'justifying faith' as a condition of our salvation, for 'we rely wholly upon the vicarious faith of Christ and not upon ourselves even in the act of faith'. It is only as we rely on the vicarious faith of Christ that we are truly free to believe without the 'ulterior motive of using faith to secure our salvation'. Thus, faith must rest on 'thanksgiving' for all that Christ has done for us, both from the side of God and from the side of man.

Like justification, Torrance regards sanctification as a fait accompli in the vicarious act of Jesus. Sanctification is an intrinsic aspect of the incarnation. Throughout the whole course of his filial obedience to the Father, Jesus sanctified the fallen human flesh he assumed, healing our corruption and reconciling sinful humanity to the Father. According to Torrance, the hypostatic union is itself a 'redeeming event'. In the incarnation of Jesus Christ, sinful human nature is 'sanctified', as it is brought into healing, reconciling union with Christ's holy nature (Torrance 1960:231, 232; 1988:162). Therefore, sanctification is not a life-long process we undergo in the pursuit of holiness. Rather, the incarnation 'is itself the sanctification of our human life in Jesus Christ' (Torrance 2008:66). In the communion of the Spirit, we subjectively participate in the objective reality of human sanctification (cf. Radcliff 2016:139).

The objective reality of sanctification, however, does not mean that, with a wink and a nod, we may cavalierly dismiss the many New Testament admonitions to godly living. After asserting God's utter, complete and irrevocable love for all, as revealed in Christ, Torrance (1992:94) admonishes his readers to 'repent and believe' and to 'renounce yourself, take up your cross and follow Jesus as your Lord and Saviour'. As Eugenio (2015:76) rightly notes, Torrance insists that we cannot stand in aloofness to God, for to be neutral before God, is to be hostile to God.

In regard to godly living, Torrance (Eugenio 2015:73 n 157) asserts that 'doing' is a consequence of 'being'. ${ }^{12}$ Given the onto-relational nature of reality, sanctification is not the result of autonomous moral effort, but rather the ontological transformation of our 'being' in union with Christ. Because sanctification is vicariously realised for all in the 'wonderful exchange' effected in the incarnation, we need not turn inward to examine ourselves for evidence of repentance (Radcliff 2016:123-126). Rather, as Torrance (2009:371; Radcliff 2016:172) notes, the church is to be continually directed away from itself to find its justification and sanctification in Christ alone. According to Torrance, we are to fix our eyes on Jesus, who has already sanctified us in his incarnate holiness and vicarious life of perfect filial obedience to the Father (cf. Radcliff 2016:167ff.; Torrance 1960:231, 232).

12.In an unpublished sermon, Torrance (Eugenio 2015) writes:

There is no more damnable heresy in the Church today than the idea that to become a Christian means to become good. If you become a Christian you WILL become good; but that is the only way. (p. 73, n. 157) 
The objective reality of our sanctification in Christ means that we enjoy a new identity. Torrance believes that we must take seriously the New Testament description of Christians as 'saints' (Radcliff 2016:156). With Barth (1936-1977, IV.2:511, 516-518), Torrance follows the Reformed tradition in asserting Luther's conviction that the believer is simul justus et peccator. Yet, Torrance asserts that justus is our primary ontological reality (Radcliff 2016:151). Nevertheless, while our sanctification is ontologically and fully realised in the incarnation, it remains 'hidden with Christ in God' (Col 3:3), waiting to be unveiled in the parousia of Jesus (cf. Torrance 2009:412). ${ }^{13}$

In summary, all aspects of the subjective human response in salvation including faith, justification and sanctification are fully realised for all humanity in the incarnation and vicarious humanity of Jesus Christ. ${ }^{14}$ For Torrance, in keeping with the Reformed tradition, salvation is 'all of grace'. Yet, 'all of grace' does not mean 'nothing of man' (Torrance 1986:480; 1992:95). Rather, by grace, we actively participate in Christ's vicarious activity on our behalf through the communion of the Spirit so that we may experience, enjoy and bear witness to the reality of the salvation that is already ours in union with Christ.

\section{The range of the Spirit's ministry}

An important aspect of Torrance's doctrine of union with Christ concerns the 'range' or 'scope' of the Spirit's ministry. This is fundamentally important for Torrance (1959:cxi), for the matter at stake concerns the biblical teaching that the Spirit has been 'poured out on all flesh' (Ac 2:17). The interpretation of this passage depends upon how one understands the doctrine of union with Christ. If all are included in the union established between God and humanity in the incarnate Jesus, then we must conclude that the range of the Spirit's ministry is universal, that is, it includes all humanity. On the other hand, if only the 'elect' or only those who 'believe in' Jesus are in union with God, then the range or scope of the Spirit's activity is limited rather than universal. Our understanding of the range of the Spirit's ministry depends upon our understanding of the incarnation. According to Torrance (1959:cxi, cxii), we must ask whether the eternal Word entered into a generic relationship with humanity simply by becoming one particular man so that his humanity has no transforming relation with our humanity, or did the eternal Word enter into an ontological relation with all humanity in the assumption of our human flesh?

To answer these questions, Torrance (1959) reminds us that the eternal Word who assumed human flesh from the virgin Mary is ' $\mathrm{He}$ in whom all men cohere for He is the Creator

13.According to Radcliff (2016:150), Torrance follows Calvin in asserting that the church manifests, at least partially, the glory of the new creation in the present age. Torrance (1959:cxxi) describes the church as 'the new humanity within the world, the provisional manifestation of the new creation within the old'.

14.In Torrance's theology, Cassidy (2008) notes that,

All of the traditional ordo salutis is encapsulated objectively in Jesus Christ. Jesus Christ lives for man vicariously, such that all he is and does he is and does for us. If we want to know where our justification is, we find it in Christ. If we want to know where our faith is, we look to Christ who believed for us. Christ is objectively our all and all. (p. 166) who gives them being and through His Spirit holds them in being.' Thus, there is an ontological relation between the eternal Word and all humanity. As Torrance argues:

[T] he Son and Word of God became man by becoming one particular Man, but because He is the Creator Word who became Man, even as the incarnate Word He still holds all men in an ontological relation to Himself. That relation was not broken off with the Incarnation. (p. cxii)

Torrance (1959) writes:

The Biblical teaching is quite explicit that in Christ all things are really involved in reconciliation, that He is not only the Head of believers but the Head of all creation and that all things visible and invisible are gathered up and cohere in him - from which we cannot exclude a relation in being between all men and Christ. ... [A]s the Head of all men [Christ] died for all men, so that all men are involved already objectively in His human life and in His work in life and death, i.e. not only on judicial and transactional grounds, but on the ground of the constitution of His Person as Mediator. (p. cxiii)

According to Torrance (1959:cxiv), humans have no being apart from Christ as man. If Christ had not come, notes Torrance, that is, if the incarnation had not taken place, so that man's estrangement with God was allowed to stand, humanity would disappear into nothing. The incarnation, including the cross, affects the entire cosmos, including all humanity so that creation itself is set on a new basis with God, 'the basis of a Love that does not withhold itself but only overflows in pure unending Love'.

In Torrance's view (1959:cxvii), there is a sense in which we must think of all humanity as 'ingrafted' into Christ by virtue of his incarnational reconciliation. It is in correlation to the universal inclusion of all humanity in Christ that we are to think of the range of the Spirit's activity. That is, the hypostatic union establishes the 'field' of the Spirit's ministry - a field that is universal in scope. Thus, we must take seriously the biblical assertion that the Spirit has been 'poured out on all flesh' and operates on 'all flesh'.

\section{Summary}

According to T.F. Torrance, union with Christ is fully and objectively accomplished for the whole of humankind in the incarnation and vicarious humanity of Christ. The union of God and humanity in the incarnation is an atoning, reconciling, sanctifying union wherein humanity is ontologically transformed and raised into the communion of the holy Trinity. In Jesus, all humanity is elected for salvation. Union with Christ is a single reality incorporating distinguishable but inseparable ontological and pneumatological relations. All aspects of the human response to God's salvific act are objectively and subjectively realised in Christ. Through the communion of the Holy Spirit who has been 'poured out on all flesh', humanity is enabled to participate in the objective work of Christ accomplished for all.

\section{Critique}

Torrance's assertion that union with Christ is a fait accompli in Jesus is compelling. The objective reality of union with God 
through Christ, established for all in the incarnation and earthly life of Jesus, offers assurance for the believer, while facilitating a positive evangelical proclamation that calls for a response to God's unconditional love for all as revealed in Christ. Moreover, Torrance's view of justification by the faithfulness 'of' Jesus alleviates concerns for the adequacy of personal faith, for the believer's faith is grounded in and undergirded by Christ's vicarious faith. At the same time, Torrance's assertion of the objective reality of sanctification in Jesus displaces the need for legalistic moral effort to achieve righteousness in favour of the liberating awareness that we already share in the perfect faith and obedience of Christ. Torrance's profoundly ontological understanding of human salvation, as worked out in the vicarious humanity of Christ, means that humanity is liberated to freely participate through the communion of the Spirit in the life, love and light of the holy Trinity. The body of Christ is indebted to Torrance for his persistent insistent that salvation is 'all of grace'.

\section{The issue of subjective response}

Torrance's assertion of union with Christ as a fait accompli, however, raises questions regarding the place of the subjective (i.e. personal) response of faith to God's goodness. Given the objective reality of our union with Christ, what role, if any, remains for the believer? Because all are objectively included in union with Christ, does this mean that there is no significance to our choices so that we are free to do as we please (Deddo 2007:144)? ${ }^{15}$ Does the profound objectivity of union with Christ, wherein faith, justification and sanctification are fully realised for all in Jesus, render personal faith and obedience redundant?

As Cassidy (2008:166) notes, there is a lack of agreement among Torrance scholars regarding Christ's objective work pro nobis and Christ's subjective work in nobis. To be sure, critics argue that Torrance fails to pay sufficient attention to the subjective personal response of faith and obedience in his doctrine of union with Christ (Radcliff 2016:94-97). According to Eugenio (2015:75), 'Torrance's radical emphasis on the objective vicarious act of Christ raises the suspicion of a neglect of the subjective pole in salvation.' For Eugenio (2015:73), Torrance's Christocentric soteriology may promote human passive participation, because humanity's only role in redemption is to share in what Christ has already done for us and in us.

As Colyer (2001:113) rightly states, this is a controversial area in Torrance's theology. For example, in an oft-cited criticism, Thomas Smail (2004:109) who appreciates Torrance's emphasis on Christ's vicarious response on behalf of all, is dissatisfied with Torrance's failure to account for the New Testament teaching that 'Christ's response on my behalf has to become my own response to Christ before it can take effect in me.' While we cannot respond to Christ 'by ourselves', argues Smail, we must respond 'for ourselves'. Smail's concern for Torrance's relative lack of attention to the subjective response of faith is understandable, given Torrance's emphasis on the objective aspects of union with Christ.

Critics notwithstanding, however, Torrance does not diminish the importance of personal faith and response to grace. To the contrary, Torrance asserts that a personal response of faith by the Spirit is necessary for the subjective actualisation of our objective, ontological union with Christ (Radcliff 2016:94). In an act of grace, the Spirit creates and calls forth the human response of faith, thanksgiving, worship and prayer (Torrance 1959:cv), so that the believer may participate in Christ's vicarious response of faith. At the same time, Torrance (1971:58) adamantly maintains that personal faith is not a condition for salvation. To make salvation dependent on a 'personal decision' of faith is to take the responsibility for salvation off the shoulders of Jesus and put it back upon ourselves. Contrary to Smail, Torrance $(1957: 114 ; 1992: 82,83)$ resists any assertion that we must believe 'for ourselves'. In his consistent emphasis on salvation as 'all of grace', Torrance emphatically asserts that we do not believe 'for ourselves', because Jesus has already believed for us.

A similar argument can be made to support Torrance's assertion that justification and sanctification are objectively realised for all in the vicarious act of Christ. Torrance does not diminish the importance of obedience and holy living. According to Torrance, we cannot know God in the absence of piety or godly living. ${ }^{16}$ To know God, writes Torrance (1988:3), 'we must enter into an intimate and saving relationship with him in Jesus Christ'. Thus, he admonishes his readers and listeners to take up the cross and follow Jesus. Nevertheless, Torrance asserts that sanctification or godly living is not achieved through a muscular process of moral effort. Sanctification has already been achieved for all in the atoning, sanctifying union of God and humanity in the person of Jesus. In contrast to a legalistic striving for holiness, aided by the Spirit, the Spirit liberates the believer to participate or share in Christ's vicarious faith and obedience (cf. Radcliff 2016:163). Hence, the believer is set free to rely on Christ's vicarious act in all aspects of the human response to grace.

As Radcliff (2016:97; cf. Lee 2003:313) observes, however, there is an enigmatic quality to Torrance's assertion that our human response is a 'participation' in Christ's response. To be sure, Torrance does not adequately articulate 'how' our human response relates to Christ's response. As Radcliff notes, however, this would not be troubling for Torrance, for God's self-revelation in Jesus takes priority over human rational thought. Nevertheless, Torrance's assertion that we 'participate' in Christ's vicarious act 'by the Spirit' appears inadequate and in need of further clarification and development. Additional research into the relationship

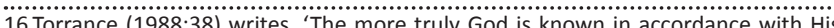
nature, the more godliness is advanced, and the more godliness is advanced the more likely we are to know God in a godly way that is worthy of His nature as God!' more likely we are to know God in a godly way that is worthy of His nature as God.'
For Torrance (1988:49), 'Piety and truth, godliness and accuracy, belong inseparably For Torrance (1988:49), 'Piety and truth, godliness and accuracy, belong
together in authentic knowledge of God through Jesus Christ his Son.' 
between the Spirit and the vicarious act of Jesus may shed much needed light on the relationship between the Spirit and our personal response of faith and obedience.

Moreover, while Torrance (1992:86-92) asserts that we participate in Christ's vicarious act, particularly through worship, prayer and the Eucharist, his idea of participation by the Spirit could be greatly enriched by incorporating a number of ecumenical practices, whether centring prayer, lectio divina, the charismatic-Pentecostal practice of 'praying in the Spirit', meditative walking (e.g. 'the labyrinth') or praise singing and sacred dance. To be sure, 'participation' may include a number of activities wherein the Spirit lifts up the mind and heart into the communion of the holy Trinity.

\section{The issue of universalism}

Torrance's assertion of universal reconciliation and the election of the whole of humanity in Christ attracts the charge of universalism (Radcliff 2016:40). According to Eugenio (2015:75), 'the critique of universalism against Torrance is the twin sister of the critique of his neglect of our human involvement in salvation'. Torrance, however, clearly rejects universalism, for it ignores the reality of hell and the necessity of mission, while disregarding the irrational, inexplicable nature of sin and evil (Radcliff 2016:40-43; Torrance 1949:311-313, 318). Torrance's assertion of a unityin-distinction between the ontological and pneumatological relations of union with Christ precludes universalism, for it leaves room for a distinct (not separate) work of the Spirit (cf. Radcliff 2016:93). While the whole of humanity is objectively included in union with Christ through the incarnation, not all participate until the objective union is subjectively actualised in the believer by the ministry of the Spirit. Contrary to charges of universalism, for Torrance (1949:312), subjective actualisation of union in Christ by the Spirit is not automatic, for, like Judas Iscariot, one may inexplicably reject the love of God and choose hell.

Torrance may appear to be splitting theological hairs by asserting 'one union' in 'two relations'. However, Torrance's 'unity in distinction' guards against a dualism between the work of the Son and the work of the Spirit by asserting only 'one work' of salvation, where the objective union with Christ accomplished for all in the incarnate life of Jesus is subjectively realised in the believer by the Holy Spirit. By asserting a distinction between ontological and pneumatological 'relations', Torrance does not collapse union with Christ into the hypostatic union with no room left for the work of the Spirit in the believer (cf. Radcliff 2016:94). Moreover, Torrance's assertion of one union in two relations guards against an element of human co-operation in redemption. If union with Christ is not a fait accompli in Jesus, the possibility of co-redemption remains where union with Christ is effected either by participation in the sacraments or by a 'personal decision' of faith. Torrance asserts that any notion of 'two unions' could present God's grace as conditional. In keeping with the Reformed tradition, Torrance steadfastly resists any notion of human co-operation in salvation.

\section{Acknowledgements Competing interests}

The author declares that he has no financial or personal relationships which may have inappropriately influenced him in writing this article.

\section{References}

Barth, K., 1936-1977, Church dogmatics, 4 vols., ed. G. Bromiley \& T. Torrance, T\&T Clark, Edinburgh.

Billings, J.T., 2011, Union with Christ: Reframing theology and ministry for the church, Baker Academic, Grand Rapids, MI.

Calvin, J., 2008, Institutes of the Christian religion, transl. H. Beveridge, Hendrickson, Peabody, MA.

Cassidy, J.J., 2008, 'T.F. Torrance's realistic soteriological objectivism and the elimination of dualisms: Union with Christ in current perspective', Mid-America Journal of Theology 19, 164-194.

Chung, T., 2011, Thomas Torrance's mediations and revelation, Ashgate, Farnham, Surrey.

Colyer, E.M., 2001, How to read T.F. Torrance: Understanding his Trinitarian \& scientific theology, InterVarsity Press, Downers Grove, IL.

Davis, M.M., 2012, 'An explanatory account and examination of the doctrine of the mediation of Jesus Christ in the scientific theology of T.F. Torrance', PhD thesis, North-West University, Potchefstroom, South Africa, Greenwich School of Theology (UK).

Dawson, G.S., 2007, 'Far as the curse is found: The significance of Christ's assuming a Fallen human nature in the Torrance theology', in G. Dawson (ed.), An introduction to Torrance theology: Discovering the incarnate saviour, pp. 55-74, T\&T Clark, London.

Dearborn, T., 1989, 'God, grace and salvation', in T. Hart \& D. Thimell (eds.), Christ in our place: The humanity of God in Christ for the reconciliation of the world: Essays presented to James Torrance, pp. 265-293, Paternoster, Exeter, UK.

Deddo, G.W., 2007, 'The Christian life and our participation in Christ's continuing ministry', in G. Dawson (ed.), An introduction to Torrance theology: Discovering the incarnate Saviour, pp. 135-156, T\&T Clark, London.

Eugenio, D.O., 2015, Communion with the triune God: The Trinitarian soteriology of T.F. Torrance, Pickwick, Eugene, OR. (Princeton Theological Monograph Series, 204).

Gill, T.C., 2007, 'The doctrine of revelation in the theology of Thomas F. Torrance', PhD thesis, School of Theology and Religious Studies, University of Leeds.

Habets, M., 2009, Theosis in the theology of Thomas Torrance, Ashgate Publishing Farnham, Surrey.

Habets, M., 2013, Theology in transposition: A constructive appraisal of T.F. Torrance, Fortress Press, Minneapolis, MN.

Lee, K.W., 2003, Living in union with Christ: The practical theology of Thomas F. Torrance, Peter Lang, New York.

MacLean, S.S., 2012, Resurrection, apocalypse, and the kingdom of Christ: The eschatology of Thomas F. Torrance, Pickwick, Eugene, OR. (Princeton Theological Monograph Series, 181).

McGrath, A.E., 1999, T.F. Torrance: An intellectual biography, T\&T Clark, Edinburgh.

Molnar, P.D., 2009, Thomas F. Torrance: Theologian of the Trinity, Ashgate Publishing, Farnham, Surrey.

Purves, A., 2015, Exploring Christology and atonement: Conversations with John McLeod Campbell, H.R. Macintosh and TF. Torrance, InterVarsity Press, Downers Grove, IL.

Radcliff, A.S., 2016, The claim of humanity in Christ: Salvation and sanctification in the theology of T.F. and J.B. Torrance, Pickwick, Eugene, OR. (Princeton Theological Monograph Series, 222).

Smail, T., 2004, The giving gift: The Holy Spirit in Person, Wipf \& Stock, Eugene, OR.

Spiedell, T., 2016, Fully human in Christ: The incarnation as the end of Christian ethics, Wipf \& Stock, Eugene, OR.

Stamps, R.J., 2013, The sacrament of the word made flesh: The Eucharistic theology of Thomas F. Torrance, Wipf \& Stock, Eugene, OR.

Torrance, T.F., 1949, 'Universalism or election?', Scottish Journal of Theology 2, 310318. https://doi.org/10.1017/S0036930600004713

Torrance, T.F., 1957, 'One aspect of the biblical conception of faith', The Expository Times 68, 111-114. https://doi.org/10.1177/001452465706800405

Torrance, T.F., 1959, The school of faith: The Catechisms of the reformed church, James Clark \& Co., London.

Torrance, T.F., 1960, 'Justification: Its radical nature and place in reformed doctrine and life', Scottish Journal of Theology 13, 225-246.

Torrance, T.F., 1971, God and rationality, Oxford University Press, London.

Torrance, T.F., 1980, The ground and grammar of theology: Consonance between theology and science, T\&T Clark, Edinburgh.

Torrance, T.F., 1981, Christian theology and scientific culture: Comprising the theological lectures at the Queen's University, Belfast for 1980, Oxford University Press, New York. 
Torrance, T.F., 1986, 'Karl Barth and the Latin Heresy', Scottish Journal of Theology 39, 461-482. https://doi.org/10.1017/S0036930600031070

Torrance, T.F., 1988, The Trinitarian faith: The evangelical theology of the ancient Catholic church, T\&T Clark, London.

Torrance, T.F., 1992, The mediation of Christ, rev. edn., Helmers \& Howard, Colorado Springs, $\mathrm{CO}$

Torrance, T.F., 1993, 'The atonement. The singularity of Christ and the finality of the cross: The atonement and the moral order', in N. Cameron (ed.), Universalism and the doctrine of hell, pp. 225-256, Baker House, Grand Rapids, Ml.
Torrance, T.F., 1994, Preaching Christ today: The gospel and scientific thinking, Eerdmans, Grand Rapids, Ml.

Torrance, T.F., 1996, Theology in reconstruction, Wipf \& Stock, Eugene, OR.

Torrance, T.F., 2002, The doctrine of Jesus Christ, Wipf \& Stock, Eugene, OR. (Auburn Lectures, 1938-1939).

Torrance, T.F., 2008, Incarnation: The Person and life of Christ, ed. R. Walker, InterVarsity Press, Downers Grove, IL.

Torrance, T.F., 2009, Atonement: The Person and work of Christ, ed. R. Walker, InterVarsity Press, Downers Grove, IL. 